\title{
Identification and analysis of a novel microsatellite marker within the growth hormone gene promoter of Colossoma macropomum (Characiformes: Characidae) detected by TAIL-PCR
}

\author{
Suhaila K. K. Jaser ${ }^{1,2}$ (D) | Caio A. Perazza ${ }^{2}$ (D) | Léia C. L. Fávaro ${ }^{3}$ (D) | Mariana A. Goto ${ }^{1}$ (D) | \\ Alzira M. de Oliveira $^{4}$ | Eric Hallerman ${ }^{5}$ (D) | Alexandre W. S. Hilsdorf ${ }^{2}$ (D)
}

${ }^{1}$ Postgraduate Program in Biotechnology, University of São Paulo, São Paulo, SP, Brazil ${ }^{2}$ Integrated Center of Biotechnology, University of Mogi das Cruzes, Mogi das Cruzes, SP, Brazil

${ }^{3}$ Brazilian Agricultural Research Corporation, EMBRAPA Agroenergy, Brasília, DF, Brazil

${ }^{4}$ Laboratory of Ecophysiology and Molecular Evolution, National Amazon Research Institute (INPA), Manaus, AM, Brazil

${ }^{5}$ Department of Fish and Wildlife Conservation, Virginia Polytechnic Institute and State University, Blacksburg, VA, USA

\section{Correspondence}

Alexandre W. S. Hilsdorf, P.O. Box 411, 08780-911 Mogi das Cruzes, SP, Brazil. Email:wagner@umc.br

Funding information

Project Tambaqui Pró-Amazônia, Grant/ Award Number: 23038009455/2013-91; Fundação de Amparo à Pesquisa do Estado de São Paulo, Grant/Award Number: 15/23.883-0; Conselho Nacional de Desenvolvimento Científico e Tecnológico, Grant/Award Number: 304662/2017-18; Research Support Foundation; INCTADAPTA; CAPES

\begin{abstract}
Summary
While in all vertebrates, growth hormone (GH) promotes post-natal growth, in fishes it also affects such metabolic functions as foraging rate, digestion, osmoregulation, and reproduction. The promoter region of the $\mathrm{GH}$ gene is an important target for studies of mechanisms regulating its expression, and polymorphisms within the promoter have been associated with performance traits in fishes. We used Thermal Asymmetric Interlaced PCR (TAIL-PCR) to amplify and sequence the $5^{\prime}$-flanking regions of the Colossoma macropomum $\mathrm{GH}(\mathrm{cmGH})$ gene. Based on a sequence of $1,038 \mathrm{bp}$, we designed three specific nested primers (R-290, R-186 and R-26) which were used with shorter arbitrary degenerate primers to amplify the $5^{\prime}$ proximal region of the $\mathrm{cmGH}$ gene. We identified a tetranucleotide (ATCC) ${ }_{4}$ microsatellite motif in this region, exhibiting four alleles $(118,122,126$ and $130 \mathrm{bp})$ within the population study. Genotypes at this locus deviated significantly from Hardy-Weinberg expectations $(p \leq .05)$ and showed a low level of polymorphism (polymorphic information content $=0.163)$. High homozygosity $\left(F_{I S}=0.147\right)$ was observed in the overall population. The polymorphism at the microsatellite makes it an important candidate for association studies between the respective genotypes, growth rate and other traits in farmed populations. Such studies may contribute to future breeding programs using marker-assisted selection upon this aquaculturally important species.
\end{abstract}

\section{KEYWORDS}

breeding program, cachama negra, short tandem repeat, polymorphism, tambaqui

\section{1 | INTRODUCTION}

Growth of vertebrates is controlled by different physiological pathways. The growth hormone (GH) axis is one of the most important pathways regulating somatic growth of body tissues (Sellier, 2000). In fish, $\mathrm{GH}$ is also involved in foraging rate, digestion, osmoregulation and reproduction (Almuly et al., 2005; Sakamoto et al., 1997; Zou et al., 1997). An increase of circulating GH levels in fish results in significant gains in growth rate (Devlin et al., 2004). Injection of $\mathrm{GH}$ increases growth rate in a number of farmed fish species. Cavari et al. (1993) showed that gilthead seabream (Sparus aurata) exhibited a $20 \%$ increase in growth rate after a treatment with native GH injection for only two weeks. Silverstein et al. (2000) determined that two different channel catfish (Ictalurus punctatus) strains had higher feed efficiency and growth rate when treated with bovine $\mathrm{GH}$. Furthermore, transgenic fishes with an exogenous GH gene copy introduced into their genomes exhibited a higher growth rate than their non-transgenic siblings (reviewed by 
Hallerman et al., 2007), as observed in coho salmon (Oncorhynchus kisutch; Devlin et al., 2004), Atlantic salmon (Salmo salar; Du et al., 1992), channel catfish (I. punctatus; Dunham et al., 1992), common carp (Cyprinus carpio; Chen et al., 1993), northern pike (Esox lucius; Gross et al., 1992) and Nile tilapia (Oreochromis niloticus; Martinez et al., 1996). Considering its importance to growth of farmed animals, molecular characterization of the entire $\mathrm{GH}$ gene or its cDNA has been carried out for chicken (Kuhnlein et al., 1997), cattle (Curi et al., 2006; Pereira et al., 2005), goat (Zhang et al., 2011) and several fishes (e.g., Tinca tinca; Kocour \& Kohlmann, 2011; pacu, Piaractus mesopotamicus; Pinheiro et al., 2008).

Physiological mechanisms underlying tissue maintenance and somatic growth have been assessed in studies investigating the activation and regulation of the $\mathrm{GH}$ gene in vivo in $\mathrm{GH}$-deficient rats and cultured cells (Woelfle et al., 2003). Thus, the expression of this gene is known to be controlled by pituitary-specific transcription factors, which bind to cis elements in the promoter, rich in AT sequences (Yowe \& Epping, 1995). Ma et al. (2012) identified binding sites for four transcription factors-Pit1/GHF-1, CRE, HNF-3 $\beta$ and TER-in the GH gene promoter of tongue sole (Cynoglossus semilaevis). Moriyama et al. (2006) identified binding sites for three transcription factors-Pit-1/IGF-1, CRE and TER-in the $\mathrm{GH}$ gene promoter of sea lamprey (Petromyzon marinus), one of the most ancient vertebrates. These results demonstrate that the $\mathrm{GH}$ gene of teleosts is regulated by synergistic interactions among a number of transcription factors within the promoter region, wherein Pit-1/IGF-1, HNF-3 $\beta$ and TER are specifically responsible for promoter activation (Yamada et al., 1993). Thus, the promoter is an important target for studies of regulatory mechanisms of the $\mathrm{GH}$ gene. Polymorphisms within the $\mathrm{GH}$ promoter have been associated with performance characters of fishes (reviewed by De-Santis \& Jerris, 2007), including growth in Atlantic salmon (S. salar; Gross \& Nilsson, 1999) and gilthead sea bream (Sánchez-Ramos et al., 2006), morphometric traits in Nile tilapia (Blanck et al., 2009).

Our model system, tambaqui, (Colossoma macropomum), known as cachama in Spanish-speaking countries, is distributed throughout the Amazon and Orinoco river basins (Araujo-Lima \& Goulding, 1998). It is the second-largest species in the Amazon basin, and can reach one meter in total length and $30 \mathrm{~kg}$ in weight (Isaac \& Ruffino, 1996). It is the object of an important freshwater fishery in the Amazon River and tributaries and is the second-largest Brazilian aquaculture species in production volume, which amounted to $101,079,464$ tons in 2019 (Corrêa et al., 2014; IBGE, 2019).

Considering the lack of information for members of Order Ostariophysi and for Neotropical fishes generally, to gain insight into mechanisms regulating expression of the $\mathrm{GH}$ gene and any polymorphism in the $\mathrm{GH}$ promoter, we: (i) characterized the $\mathrm{GH}$ gene promoter of $C$. macropomum using TAIL PCR methodology, (ii) determined the presence of short tandem repeats (STR) polymorphism in the GH promoter sequence, and (iii) assessed the level of STR polymorphism in different $C$. macropomum populations.

\section{2 | MATERIALS AND METHODS}

\subsection{Isolation of the $5^{\prime}$ flanking region of the $C$. macropomum $\mathrm{GH}$ gene}

\subsubsection{Sequencing of the GH gene intron-I}

Genomic DNA was isolated using the phenol-chloroform method (Sambrook \& Russell, 2006) from a wild tambaqui caudal fin-clip sample stored in $95 \%$ ethanol. To characterize the $5^{\prime}$ flanking region of the C. macropomum $\mathrm{GH}$ gene $(\mathrm{cmGH})$ gene, we applied the Thermal Asymmetric Interlaced PCR (TAIL-PCR) methodology (Liu \& Whittier, 1995), which permits amplification of an unknown genomic region for which only partial sequence information is available (Session et al., 2002). The coding region of the $\mathrm{GH}$ gene being highly conserved among vertebrates (Ma et al., 2012), we inferred the positions of introns within the $\mathrm{cmGH}$ gene by aligning complete $\mathrm{GH}$ sequences from other fish species (Almuly et al., 2000; Ber \& Daniel, 1992; Ma et al., 2011; Poen \& Pornbanlualap, 2013; Sekkali et al., 1999; Yowe \& Epping, 1995). As the exon-I sequence is not transcribed into the $\mathrm{GH}$ mature hormone because it is part of the signal peptide sequence (Miller \& Eberhardt, 1983), we characterized $\mathrm{GH}$ intron-I based on the $\mathrm{CDNA}$ sequence of the $\mathrm{GH}$ gene for C. macropomum (Souza et al., 2016; GenBank: KU312263.1) to design the primers (TambF-1: ATGGCTAAAGGATTGGTGCTGCTC; TambR-224: GAGTCAGAATTGCAGAAGGACAG) using the Primer3 tool (Untergasser et al., 2012).

The conditions for PCR amplification of intron-I were carried out in a final volume of $50 \mu \mathrm{l}$ containing Taq Buffer $1 \mathrm{X} ; 3.7 \mathrm{mM} \mathrm{MgCl}$; $0.2 \mathrm{mM}$ dNTPs; $0.2 \mu \mathrm{M}$ of each primer; $0.2 \mathrm{U} / \mu \mathrm{l}$ of Taq DNA polymerase and $2 \mu$ of DNA template, performed in a MJ Research thermocycler, with initial denaturation at $94^{\circ} \mathrm{C}$ for 5:00 min; followed by 34 cycles with denaturation at $94^{\circ} \mathrm{C}$ for $1: 00 \mathrm{~min}$, annealing at $60^{\circ} \mathrm{C}$ for $1: 00 \mathrm{~min}$ and extension at $72^{\circ} \mathrm{C}$ for $1: 30 \mathrm{~min}$; and finishing with an extension at $72^{\circ} \mathrm{C}$ for 7:00 min. The product was analyzed in $1.5 \%$ agarose gels and purified with the Illustra ${ }^{\mathrm{TM}} \mathrm{GFX}^{\mathrm{TM}}$ PCR DNA and Gel Band Purification kit (GE Healthcare). The DNA sequencing was carried out on an $\mathrm{ABI}$ Prism ${ }^{\mathrm{TM}}$ 3,730 DNA Analyzer (Applied Biosystems) using the BigDye ${ }^{\circledR}$ Terminator $v$ 3.1. The consensus sequences were generate using CodonCode Aligner software, version 3.7.1 (http://www.codoncode.com/aligner/). All consensus sequences were aligned using the ClustalW tool (Higgins, 1994) implemented in MEGA5 software (Tamura et al., 2011) and optimized by eye using Bioedit version 7.0.9.0 (Hall, 1999).

\subsubsection{TAIL-PCR for isolation of the $\mathrm{cmGH}$ gene $5^{\prime}$ flanking region}

To perform TAIL-PCR (Liu \& Whittier, 1995), we designed three nested reverse primers (R-290, R-186 e R-26; Table 1) based on the $\mathrm{GH}$ intron-I and cDNA sequences. Each specific primer was tested with six shorter arbitrary degenerate primers (AD2 to AD7; Amadeo et al., 2000; Parinov et al., 2004; Session et al., 2002; see Table 1) 
TABLE 1 Primers tested in TAIL-PCR reactions for amplification of the initial region of tambaqui (Colossoma macropomum) $\mathrm{GH}$ gene

\begin{tabular}{|c|c|c|}
\hline Primer & Sequence $\left(5^{\prime}-3^{\prime}\right)$ & Reference \\
\hline $\mathrm{R}-290$ & CACTGCAGAGTTAAATCGGTGA & $\begin{array}{l}\text { Designed in } \\
\text { this work }\end{array}$ \\
\hline $\mathrm{R}-186$ & GATGACTGCATTGTTGAAGAGC & $\begin{array}{l}\text { Designed in } \\
\text { this work }\end{array}$ \\
\hline $\mathrm{R}-26$ & GAGAGCAGCACCAATCCTTTAG & $\begin{array}{l}\text { Designed in } \\
\text { this work }\end{array}$ \\
\hline AD2-S & TGWGNAGSANCASAGA & $\begin{array}{l}\text { Session } \\
\text { et al. (2002) }\end{array}$ \\
\hline AD3-S & AGWGNAGWANCAWAGG & $\begin{array}{l}\text { Session } \\
\text { et al. (2002) }\end{array}$ \\
\hline AD5-P & WCAGNTGWTNGTNCTG & $\begin{array}{l}\text { Parinov } \\
\text { et al. (2004) }\end{array}$ \\
\hline AD11-P & NCASGAWAGNCSWCAA & $\begin{array}{l}\text { Parinov } \\
\text { et al. (2004) }\end{array}$ \\
\hline AD6-A & WGCNAGTNAGWANAAG & $\begin{array}{l}\text { Amadeo } \\
\text { et al. (2000) }\end{array}$ \\
\hline AD7-A & AWGCANGNCWGANATA & $\begin{array}{l}\text { Amadeo } \\
\text { et al. (2000) }\end{array}$ \\
\hline
\end{tabular}

Abbreviation: $\mathrm{GH}$, growth hormone; TAIL-PCR, Thermal Asymmetric Interlaced PCR.

to amplify the target region. The TAIL-PCR process consisted of three successive reactions. In the primary PCR amplification, specific primer (R-290), annealing farthest from the target region, was used with the genomic DNA template. In the secondary reaction, the primer (R-186), with the intermediate binding site, was used with the product of the first reaction. Finally, in the tertiary reaction, the specific primer (R-26), binding closest to the target region, was used with the product of the second reaction. In each reaction step, each one of the specific primers was tested using all of the six arbitrary primers to boost the chances of successfully obtaining amplicons. The concentrations of all TAIL-PCR components are given in File S1, and the thermal cycling conditions are shown in Table 2.

The tertiary reactions PCR products were subjected to electrophoresis through a $1.5 \%$ agarose gel. The single amplicon bands with great concentration were excised from the gel, purified with the Illustra ${ }^{\mathrm{TM}}$ GFXTM PCR DNA Purification kit and cloned into Escherichia coli DH5 $\alpha$ cells using the pGEM ${ }^{\circledR}$ T-Easy Vector System (Promega). Plasmids were isolated from white colonies with the Illustra PlasmidPrep Mini Spin kit (GE Healthcare Life Sciences) and sequenced. Sequences were analyzed as described above, and the 3' end of each sequence was evaluated to verify that it could align with the $5^{\prime}$ end of the cDNA sequence.

\subsection{Characterization of the $\mathrm{cmGH}$ gene 5' flanking region and identification of microsatellite}

By aligning and comparing the sequence of the $5^{\prime}$ flanking region of the $\mathrm{cmGH}$ gene with those of other teleost $\mathrm{GH}$ gene sequences and
TABLE 2 Cycle settings used for TAIL-PCR. Modified from Liu and Whittier (1995)

\begin{tabular}{|c|c|c|}
\hline Reaction & $\begin{array}{l}\text { Cycles } \\
\text { number }\end{array}$ & Thermal settings \\
\hline \multirow[t]{8}{*}{ Primary } & 1 & $94^{\circ}$ for $2 \mathrm{~min} ; 95^{\circ}$ for $1 \mathrm{~min}$ \\
\hline & 5 & $\begin{array}{l}94^{\circ} \text { for } 30 \mathrm{~s} ; 66^{\circ} \text { for } 1 \mathrm{~min} ; 72^{\circ} \text { for } \\
2: 30 \min \end{array}$ \\
\hline & 1 & $\begin{array}{l}94^{\circ} \text { for } 30 \mathrm{~s} ; 30^{\circ} \text { for } 3 \mathrm{~min} ; 72^{\circ} \text { for } \\
3 \mathrm{~min} ; 72^{\circ} \text { for } 2 \mathrm{~min}\end{array}$ \\
\hline & 10 & $\begin{array}{l}94^{\circ} \text { for } 5 \mathrm{~s} ; 44^{\circ} \text { for } 1 \mathrm{~min} ; 72^{\circ} \text { for } \\
2: 30 \mathrm{~min}\end{array}$ \\
\hline & 15 & $\begin{array}{l}94^{\circ} \text { for } 5 \mathrm{~s} ; 66^{\circ} \text { for } 1 \mathrm{~min} ; 72^{\circ} \text { for } \\
2: 30 \min \end{array}$ \\
\hline & 15 & $\begin{array}{l}94^{\circ} \text { for } 5 \mathrm{~s} ; 66^{\circ} \text { for } 1 \mathrm{~min} ; 72^{\circ} \text { for } \\
2: 30 \min \end{array}$ \\
\hline & 15 & $\begin{array}{l}94^{\circ} \text { for } 5 \mathrm{~s} ; 44^{\circ} \text { for } 1 \mathrm{~min} ; 72^{\circ} \text { for } \\
2: 30 \mathrm{~min}\end{array}$ \\
\hline & 1 & $72^{\circ}$ for $7 \mathrm{~min}$ \\
\hline \multirow[t]{4}{*}{ Secondary } & 15 & $94^{\circ}$ for $10 \mathrm{~s} ; 66^{\circ}$ for $1 \mathrm{~min} ; 72^{\circ}$ for $2 \min$ \\
\hline & 15 & $94^{\circ}$ for $10 \mathrm{~s} ; 66^{\circ}$ for $1 \mathrm{~min} ; 72^{\circ}$ for $2 \mathrm{~min}$ \\
\hline & 15 & $94^{\circ}$ for $10 \mathrm{~s} ; 44^{\circ}$ for $1 \mathrm{~min} ; 72^{\circ}$ for $2 \mathrm{~min}$ \\
\hline & 1 & $72^{\circ}$ for 5 min \\
\hline \multirow[t]{3}{*}{ Tertiary } & 1 & $94^{\circ}$ for $10 \mathrm{~s}$ \\
\hline & 30 & $94^{\circ}$ for $15 \mathrm{~s} ; 42^{\circ}$ for $15 \mathrm{~s} ; 72^{\circ}$ for $2 \min$ \\
\hline & 1 & $72^{\circ}$ for $7 \mathrm{~min}$ \\
\hline
\end{tabular}

Abbreviation: TAIL-PCR, Thermal Asymmetric Interlaced PCR.

using the PROMO tool (http://www.Isi.upc.es/ alggen; Messeguer et al., 2002), we characterized potential exon-I, intron-I and putative regulatory regions. The $5^{\prime}$ flanking region also was assessed in silico using Microsatellites Repeats Finder (http://insilico.ehu.es/ mini_tools/microsatellites/; Bikandi et al., 2004). Then, using the Primer3 package, we designed primers to amplify the short tandem repeat (STR) locus found in this region.

\section{3 | Polymorphism assessment of the STR in the 5' flanking region of the $\mathrm{cmGH}$ gene}

The polymorphism analysis was performed using 170 C. macropomum individuals from six different farmed stocks and one wild population (Figure 1). The farmed stocks were obtained from: Biofish fish farm, Porto Velho, RO (BF; 31 samples); Projeto Prosperidade, Santarém,PA (PP; 17 samples), Tajá fish farm, Manaus, AM; (TJ; 30 samples), National Department of Works Against Drought, Pentecoste, CE (DNOCS; 30 samples), Brumado fish farm, Mogi Mirim, SP (BM; 30 samples) and National Center for Research and Conservation of Continental Fish, Pirassununga, SP (CEPTA; six samples). The wild population came from Balbina Reservoir, Manaus, AM (BW; 26 samples).

The genomic DNA were isolated using a high salt concentration method (Aljanabi \& Martinez, 1997). DNA integrity and concentration 


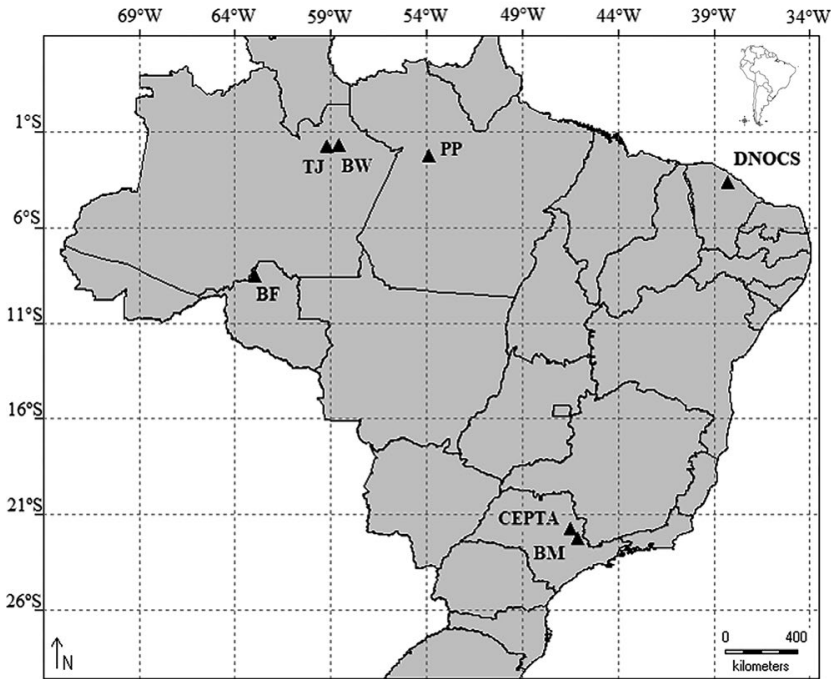

FIGURE 1 Map of sampling locations for tambaqui (Colossoma macropomum): BF, Biofish fish farm, Porto Velho-RO; BM, Brumado fish farm, Mogi Mirim-SP. DIVA-GIS (2017); BW, wild population from Balbina Reservoir, Manaus-AM; CEPTA, National Center for Research and Conservation of Continental Fishes, PirassunungaSP; DNOCS, National Department of Works Against Drought, Pentecoste-CE; PP, Projeto Prosperidade, Santarém-PA; TJ, Tajá fish farm, Manaus-AM

were assessed by electrophoresis through a $1 \%$ agarose gel with the lambda/HindIII molecular weight ladder (Fermentas). The amplification conditions were carried out in a final volume of $25 \mu$ l, containing: 1X Taq Buffer, $1.5 \mathrm{mM} \mathrm{MgCl}_{2}, 0.2 \mathrm{mM}$ of dNTPs; $0.2 \mathrm{mM}$ of each primer (Cm_MiF2 and Mi_CmR2), 2 U Taq DNA polymerase (Sinapse Biotecnologia) and $1.5 \mu \mathrm{l}$ of template genomic DNA, using a Veriti ${ }^{\circledR}$ thermal cycler (Applied Biosystems) with an initial denaturation at $95^{\circ} \mathrm{C}$ for $10 \mathrm{~min}$; followed by 35 cycles of denaturation at $94^{\circ} \mathrm{C}$ for $1 \mathrm{~min}$, annealing at $52^{\circ} \mathrm{C}$ for $1 \mathrm{~min}$, and extension at $72^{\circ} \mathrm{C}$ for $30 \mathrm{~s}$; and a final extension step at $72^{\circ} \mathrm{C}$ for $10 \mathrm{~min}$.

Electrophoresis and genotyping of the microsatellite locus were carried out in a Matrix Plus denaturing 6.5\% polyacrylamide gel inside a Li-Cor 4300 DNA Analyzer (LI-COR Biosciences, Lincoln, NE, USA) using the IRDye ${ }^{\circledR} 700$ marker (LI-COR Biosciences) and universal M13 tail primer as described by Schuelke (2000). Allele sizes were estimated by interpolating their position relative to the molecular weight markers (50-350 bp DNA Sizing Standard IRDye ${ }^{\circledR} 700$ ) using the SagaGT Client program (LI-COR Biosciences). Putative genotyping errors (Pompanon et al., 2005) were minimized by semiautomated scoring followed by visual inspection by two independent people.

The levels of polymorphism and the allelic diversity were quantified as allelic richness (Ar), allele frequencies, and genotypic frequencies using the Fstat software (Goudet, 1994). The observed $\mathrm{Ho}$ ) and expected $\mathrm{(He}$ ) heterozygosities and departures of genotype frequencies from those expected under Hardy-Weinberg equilibrium (HWE) were estimated using Arlequin 3.0 software (Excoffier et al., 2005), and the polymorphic information content (PIC) was calculated using CERVUS (Marshall et al., 1998).

\section{3 | RESULTS}

\subsection{Sequencing of the $5^{\prime}$ flanking region of the cmGH gene}

\subsubsection{Sequencing of $\mathrm{cmGH}$ gene intron-I}

A fragment of about 900 bp was obtained by the amplification of intron-I (GenBank: MN433469) of the $\mathrm{cmGH}$ gene using the primer pair TambF-1/TamR-224 and we confirmed that is was intron-I (887 bp) by its alignment in proper position relative to the cDNA (File S2).

\subsection{2 | TAIL-PCR for isolation and confirmation of the $\mathrm{cmGH}$ gene $5^{\prime}$ flanking region}

With the $\mathrm{cmGH}$ sequence of 1,038 bp (151 bp of exon-II and $887 \mathrm{bp}$ of intron-I), we designed three specific nested primers (R-290, R-186 and R-26; File S2) required to perform TAIL-PCR. By testing six different arbitrary degenerate primers, we ascertained two specific and more intense amplicons ("A" and "B"; Figure 2), which were sequenced. These bands were the PCR products of primer pairs R-26/ AD6-A and R-26/AD7-A, respectively. Assessing the alignment of sequences using ClustalW tool, the $3^{\prime}$ end of the amplicon "B" (Figure 2)

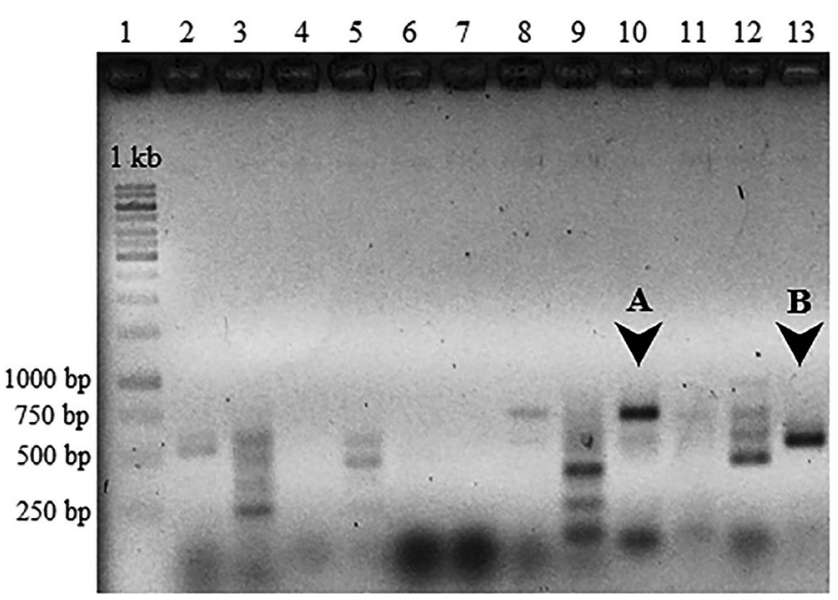

FIGURE 2 Electrophoresis gel (1.5\%) showing products of TAIL-PCR tertiary reactions for amplification of 5 ' flanking region of Colossoma macropomum GH gene. (a) product of TAIL-PCR tertiary reaction with primers R-26/AD6-A; (b) product of TAIL-PCR tertiary reaction with primers $\mathrm{R}-26 / \mathrm{AD} 7-\mathrm{A}$. (1) molecular weight reference 1 kb DNA ladder (Thermo Scientific ${ }^{\mathrm{TM}}$ ); (2) secondary reaction with primers R-186/AD2-S; (3) tertiary reaction with primers R-26/ AD2-S; (4) secondary reaction with primers R-186/AD3-S; (5) tertiary reaction with primers R-26/AD3-S; (6) secondary reaction with primers R-186/AD5-P; (7) tertiary reaction with primers R-26/AD5-P; (8) secondary reaction with primers R-186/AD11-P; (9) tertiary reaction with primers R-26/AD11-P; (10) secondary reaction with primers $\mathrm{R}-186 / A D 6-A$; (11) tertiary reaction with primers R-26/AD6-A; (12) secondary reaction with primers $\mathrm{R}-186 /$ AD-7A; (13) tertiary reaction with primers R-26/AD7-A. GH, growth hormone; TAIL-PCR, Thermal Asymmetric Interlaced PCR 
sequence was aligned with the $5^{\prime}$ end of the cDNA sequence. As a result, amplicon ' $\mathrm{B}$ ' was the TAIL-PCR product associated with the $5^{\prime}$ flanking region of the $\mathrm{cmGH}$ gene $5^{\prime}$-flanking region. Therefore, using a homemade primer design, Pm_16F (5'gcccttataacttcacccttga $^{\prime}$ ) that anneals to the beginning of the $5^{\prime}$ flanking sequence and Pm_713 (5'cgaacagaggtaaggttgaaa3') that anneals in the intronI (File S3), we confirmed that the 873-bp sequence obtained by TAILPCR was the $\mathrm{cmGH}$ gene $5^{\prime}$ flanking region (GenBank: MN433469). Further, the $3^{\prime}$ end of this fragment aligned with the $5^{\prime}$ end of $C$. macropomum cDNA sequence, which ascertains the identity of the target sequence.

\subsection{Characterization of the $\mathrm{cmGH}$ gene 5' flanking region and polymorphism evaluation}

The detailed sequence of the $5^{\prime}$ flanking region is depicted in Figure 3. Analysis of this sequence using the PROMO package and alignment with the same region of four other teleost species (Figure 4) revealed a TATA box (transcription-factor binding site) located at $-24 \mathrm{bp}$, the position of nucleotide +1 , the possible position of the start codon (ATG), and putative transcription factor binding sites for Pit-1, HNF3, AP-1, GRE, TRE and ERE (Figure 3).

The assessment of the $5^{\prime}$ flanking sequence also showed the presence of three STRs, two tetranucleotide repeats, (ATCC) $)_{4}$ and $(C A G A)_{3}$, at positions -512 and -387 , respectively and one $(A C)_{5}$ dinucleotide repeat at position -374 . No STR polymorphism was found in either exon-I or in intron-I. The tetranucleotide (ATCC) ${ }_{4}$ was selected because its molecular position to design a pair of primers (Cm_MiF2: GGGGCTTTTCTGTGATGTGG and Mi_CmR2: CAATGACAGCAGGGATAGG; File S4) to which amplify this STR region so that any polymorphisms in the proximal promoter region could be evaluated.

A total of 170 individuals from six cultured and one wild collections of $C$. macropomum were genotyped at the STR locus. The STR in the proximal $5^{\prime}$ flanking region proved to be polymorphic, with four alleles (118, 122, 126 and 130 bp) among all populations. The most frequent allele across populations was the 130-bp allele (File S5). We observed six of the 10 possible genotypes, and the most frequent in all populations was 130/130. Genotype 130/180 was found in two individuals only in population BW (File S5). Overall, this locus deviated significantly from HWE $(p<.05)$ and showed a low level of polymorphism (PIC $=0.163$ ). High homozygosity was observed in the overall population $\left(F_{\mathrm{IS}}=0.147\right)$; the observed $(\mathrm{Ho})$ and expected $(\mathrm{He})$ heterozygosites were 0.183 and 0.215 , respectively.

\section{4 | DISCUSSION}

Promoter elements are DNA sequences upstream of a gene's proteinencoding sequence that regulate in gene expression (Atkinson \& Halfon, 2014; Roy \& Singer, 2015). The structural elements of the promoter provide the transcriptional control domains for response elements and binding sites for transcription factors to recruit RNA polymerase to initiate transcription. In the $814 \mathrm{bp}$ upstream of the $\mathrm{cmGH}$ gene, we identified putative transcription factor binding sites as well as three STR tracts. Comparing the sequence of the $\mathrm{cmGH}$ $5^{\prime}$-flanking region with those of other teleosts, we observed that the TATA box has a relatively conserved position, varying from the -21 to -24 position among five species (Almuly et al., 2005; Chiou et al., 1990; Tang et al., 1993; Yowe \& Epping, 1995). Up to position -200 , all species show putative N-Oct-3 and two Pit-1 binding sites. This region is conserved among perciform fishes (Almuly et al., 2005), and includes the presence of a (CA $)_{n}$ STR tract between the Pit- 1 and HNF-3 binding sites. The putative NHF-3 binding site was detected in all species except for channel catfish (I. punctatus). However, the absence of a (CA) $)_{n}$ STR tract in the three ostariophysian species ( $C$. macropomum, I. punctatus and C. carpio) shows the higher degree of similarity among promoter sequences of species of the same phylogenetic order. Moriyama et al. (2006) demonstrated the presence of

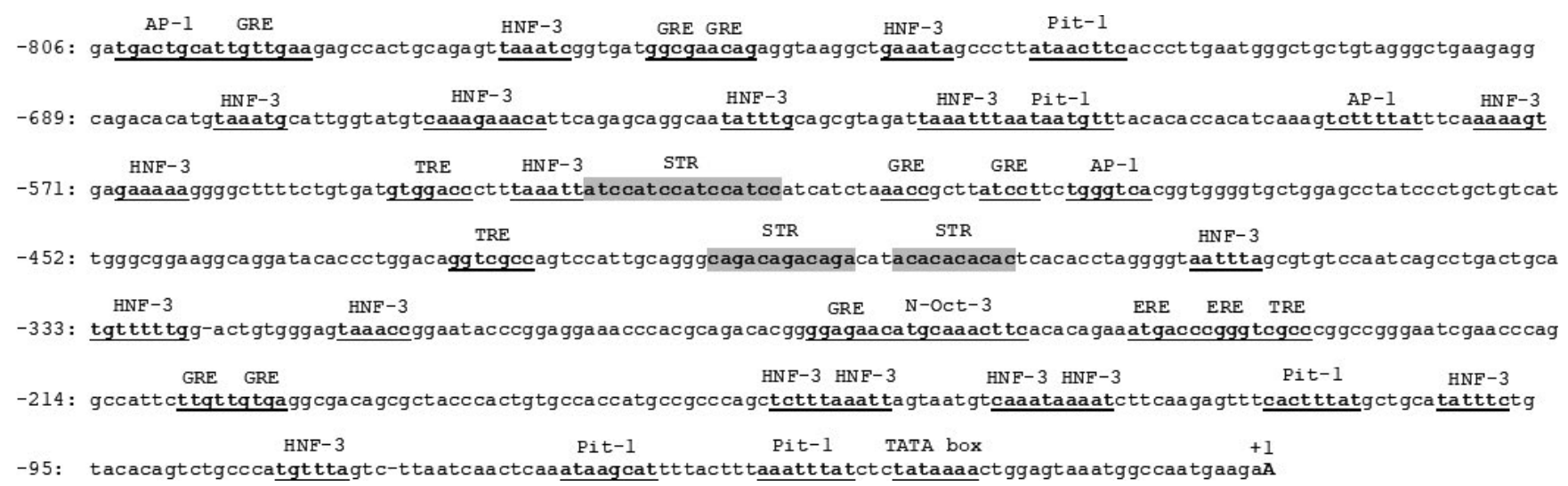

FIGURE 3 Nucleotide sequence (802 bp) of 5 ' flanking region of Colossoma macropomum growth hormone gene. TATA box and putative transcription factor binding sites are boldface and underlined; short tandem repeat sequences are highlighted in grey and +1 is used to represent transcription start point. AP-1, activating protein 1 binding element; ERE, estrogen response element; GRE, glucocorticoid response element; HNF-3, hepatocyte nuclear factor 3; N-Oct-3, neural POU-domain protein; Pit-1, binding site for pituitary-specific transcription factor; TRE, thyroid hormone response element 
CM: --------------------ttgtgaggcgacagcgctacccactgtgccaccat---gccgcccagctctttaaatta----gtaatgtcaa taaatctt SA: ---------cagtcttaaccttaatcagttcagccgtcaacatgcagagtttttatg--atccataatattattattgaggtattc----------------LC: --------aagttttactcaaatcagtttgtgacacgtcaagtttttatctcagtgtttaata--------ttattattaaggtgtta-----------------

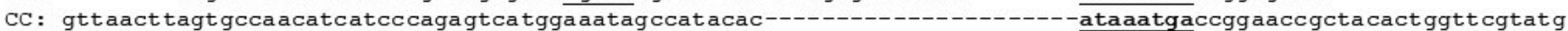
IP : ------------------tcctcctgaagtcatgaggga ataagtcacactcaaa----aacacctggaagcgtattaacgtatacctattaa ataac-----

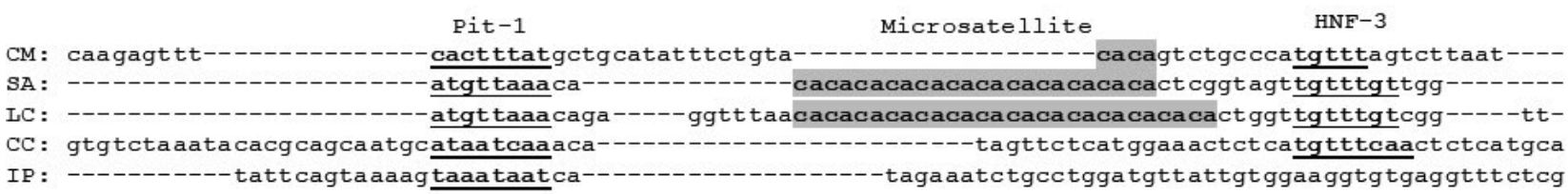

Pit-1 Pit-1 TATA box

$+1$

CM: caactcaataagcattttactttaaatttatctc---------------tataaaactggagtaaatggccaatgaagaATCTTTCATGATTCCAG $\mathrm{SA}$ : tttcatgtttctgttg-------- atgaattaattcatcaagttttctgctataaaccacaaag tctgagctgaaaat-ATCAGAACGACTGAACT LC: catgtttctgttgatgaat-----ttaatcatcaagttttcttc------tataaaaccacaaactgagctgaaaac----ATCAGATCAACTGAACC CC: ttaagatgc--------------- attaaacatgttcatgccaca----tataaatatcagtacctgagcctgaaaa---ACA-------------IP : tgtcgatgC---------------attaaacagttttagctcgtg-----tataaaatcgggccagcacaacgagggac-AAA----------GTCA

Start Codon

CM: TCCAAAGACAGGAACTGCATTAAAAGT GTAT GTATGTTAAAGATGCTTTTTCTCATTTTAAAGGATGGCTAGAG

SA: CAGATCAGATCTAGT CACCAGAACTTGAACCAAAACCAGAACCTGAACCAGAC------------ATGGACAGAG

LC: A----CTGATCCAGA-GCCAAGACCTGAACCAGAACCAGAACTGAATCCAGACCAGCC-------ATGGACAGAG

CC: ----AACATTCACAAGCTCT TAACTAAGCCTGCAAGAGTTT GTCTACCCTGAGCGAA--------ATGGCTAGAG

IP: TTCACTGAGACTCGAGACTCCAGCGAGATCTGACAAAGCTTCTTCAGAGAGATTTGGCAAA----ATGGCTAGA

FIGURE 4 Multiple alignment of the GH gene promoter region of five fish growth hormone genes (200 pb). Colossoma macropomum (CM); Cyprinus carpio (CC; Chiou et al., 1990), Ictalurus punctatus (IP; Tang et al., 1993), Sparus aurata (SA; Almuly et al., 2005) and Lates calcarifer (LC; Yowe \& Epping, 1995). The TATA box and putative binding sites for transcription factor are boldfaced and underlined. Microsatellites are highlighted in grey. Dashes represent gaps added to facilitate alignment. GH, growth hormone

putative Pit-1, CRE and TRE binding sites upstream of the GH gene of sea lamprey $P$. marinus and suggested that $\mathrm{Pit}-1$ is primarily responsible for $\mathrm{GH}$ gene expression in this species, as well as in teleosts and mammals. In C. macropomum, in addition to the putative Pit-1 binding site, we detected putative binding sites for HNF-3, AP-1, GRE, ERE, TRE and N-Oct-3, although no complementary site for CRE was found. All of these binding sites having been detected in other fish species, the presence of multiple types of binding site in all species studied suggests that $\mathrm{GH}$ gene regulation in fishes depends upon the interaction of multiple regulatory factors (Almuly et al., 2005; Argenton et al., 1996; Moriyama et al., 2006; Von Schalburg et al., 2008).

The majority of polymorphisms associated with fish GH genes occurs within introns and the proximal promoter (De-Santis \& Jerry, 2007). Putative associations of GH sequence polymorphism and growth have been reported for some fishes, such as Atlantic salmon (S. salar; Gross \& Nilsson, 1999), gilthead sea bream (S. aurata; Almuly et al., 2000; Almuly et al., 2005), Asian seabass (Lates calcarifer; Gopal et al., 2015; Yue et al., 2001), olive flounder (Paralichthys olivaceus; Kang et al., 2002), yellow catfish (Pelteobagrus fulvidraco; Li et al., 2017), common carp (C. carpio; Liu et al., 2017), and Nile tilapia (O. niloticus; Dias et al., 2019). STR polymprphism at the GH gene was related to culture history and differentiation among oceanic populaiuotns in European sea bass (Dicentrarchus labrax; Quéré et al., 2010).

STR repeats in the promoter region may affect the gene regulation, resulting in variation of levels of the protein encoded (Kashi \& King, 2006; Kashi et al., 1997; Li et al., 2004), as has been shown in yeast (Russell et al., 1983), gilthead sea bream (Almuly et al., 2008), Nile tilapia (Streelman \& Kocher, 2002), cattle (Hale et al., 2000) and human (Horan et al., 2003). In particular, STR polymorphisms in the promoter region may affect $\mathrm{GH}$ expression in fish, in turn affecting growth performance. Jaser et al. (2017) identified SNPs in the promoter region of the $\mathrm{GH}$ gene of a hatchery population of Nile tilapia and associated the markers with individual growth rate. $\mathrm{Li}$ et al. (2017) showed significant associations of variants at three STR loci with growth and several morphometric traits in yellow catfish. After introgressive crossbreeding between the Red-Stirling and Chitralada strains of Nile tilapia, Dias et al. (2019) showed that STR allelic variation at the promoter locus had a significant association with weight gain. Against this background, we note that the polymorphic STR identified in the present study is located very close to several putative complementary sequences for transcription factors, between an NHF-3 and a GRE site. Hence, we hypothesize that the contraction and expansion of such an STR array might affect the interaction of a transcription factor with the promoter, resulting in changes in the timing, location or level of $\mathrm{cmGH}$ gene expression.

The STR polymorphism in the proximal promoter of C. macropomum here reported is the first characterized in a Neotropical species of fisheries and aquaculture importance. The low genetic diversity (i.e., the low number of alleles) at the STR in the GH promoter of this species might be due to limited sampling, mostly from aquaculture stocks, to the tetranucleotide motif of this STR locus, which is characteristically less polymorphic than for di- or trinucleotide motifs, or to effects of variants upon $\mathrm{GH}$ expression and fitness.

Our findings open an avenue of population genetics investigations into whether wild populations from different locations in the Amazon 
and Orinoco basins may reveal other alleles and genotypic combinations than those that we found. The characterization of the $5^{\prime}$ flanking region of the $\mathrm{cmGH}$ gene and the primers designed for this region in the present work can be used in future studies of aquaculture stocks to observe STR polymorphisms and to test their association with growth rate or other production traits. Should such associations be found, the knowledge can be applied as a performance-related molecular marker useful for marker-assisted selection and genetic improvement of aquaculture stocks (Fuji et al., 2007; Moen, 2010; Poompuang \& Hallerman, 1997; Sonesson, 2007).

\section{ACKNOWLEDGEMENTS}

The authors gratefully acknowledge the financial support by the São Paulo Research Foundation (grant number 15/23.8830), Research Support Foundation (FAEP), INCT-ADAPTA (ProAmazonia), and Project Tambaqui Pró-Amazônia (grant number 23038009455/2013-91). S.K.K.J. is grateful to CAPES and CNPq for scholarship grants. A.W.S.H. is the recipient of Research Fellowship from CNPq (304662/2017-8). Special thanks to Silvia Eda Arranz, Juan Díaz and Gabriela Vanina Villanova from Molecular and Celular Biology Institute of Rosario, Scientific and Technological Center (CONICET), National University of Rosario (URN) for the collaboration and support during this study's execution.

\section{CONFLICT OF INTEREST}

The authors declare that they have no conflict of interest.

\section{AUTHOR CONTRIBUTIONS}

S.K.K.J. performed the experimental design, laboratory work, and drafted the paper. L.C.L.F. performed the TAIL-PCR experimental procedures. C.A.P. performed the statistical analysis. E.H. contributed to manuscript drafting and preparation. A.W.S.H. conceived the study and prepared the final version of the manuscript. All the authors have read and approved the final version to submission.

\section{DATA AVAILABILITY STATEMENT}

The online version of this article contains Supporting Information, which is available to authorized users. Growth hormone gene sequence of $C$. macropomum and its partial $5^{\prime}$ flanking region have been submitted to GenBank with accession number MN433469.

\section{ORCID}

Suhaila K. K. Jaser (iD https://orcid.org/0000-0001-8204-9999 Caio A. Perazza (iD https://orcid.org/0000-0002-4700-9657 Léia C. L. Fávaro (iD https://orcid.org/0000-0003-3260-0310 Mariana A. Goto iD https://orcid.org/0000-0001-8070-2958 Eric Hallerman (iD https://orcid.org/0000-0002-5839-858X Alexandre W. S. Hilsdorf (iD https://orcid.org/0000-0001-9565-8072

\section{REFERENCES}

Aljanabi, S. M., \& Martinez, I. (1997). Universal and rapid salt-extraction of high quality genomic DNA for PCR-based techniques. Nucleic Acids Research, 25, 4692-4693. https://doi.org/10.1093/nar/25.22.4692
Almuly, R., Cavari, B., Ferstman, H., Kolodny, O., \& Funkenstein, B. (2000). Genomic structure and sequence of the gilthead seabream (Sparus aurata) growth hormone-encoding gene: Identification of minisatellite polymorphism in intron I. Genome, 43, 836-845. https:// doi.org/10.1139/g00-051

Almuly, R., Poleg-Danin, Y., Gorshkov, S., Gorshkova, G., Rapoport, B., Soller, M., Kashi, Y., \& Funkenstein, B. (2005). Characterization of the $5^{\prime}$ flanking region of the growth hormone gene of the marine teleost, gilthead sea bream Sparus aurata: Analysis of a polymorphic microsatellite in the proximal promoter. Fisheries Science, 71, 479-490. https://doi.org/10.1111/j.1444-2906.2005.00991.x

Almuly, R., Skopal, T., \& Funkenstein, B. (2008). Regulatory regions in the promoter and first intron of Sparus aurata growth hormone gene: Repression of gene activity by a polymorphic minisatellite. Comparative Biochemistry and Physiology D: Genomics and Proteomics, 3, 43-50. https://doi.org/10.1016/j.cbd.2006.12.006

Amadeo, P., Habu, Y., Afsar, K., Scheid, O. M., \& Paszkowski, J. (2000). Disruption of the plant gene MOM releases transcriptional silencing of methylated genes. Nature, 405, 203-206. https://doi. org/10.1038/35012108

Araujo-Lima, C., \& Goulding, M. (1998). So fruitful a fish: Ecology, conservation, and aquaculture of the Amazon's tambaqui. Environmental Conservation, 25, 279-289. https://doi.org/10.1017/S037689299 8210344

Argenton, F., Bernardini, S., Puttini, S., Colombo, L., \& Bortolussi, M. (1996). A TGACG motif mediates growth hormone factor-1/pituitary-transcriptional-activator-1-dependent cAMP regulation of the rainbow trout growth-hormone promoter. European Journal of Biochemistry, 238, 591-598. https://doi. org/10.1111/j.1432-1033.1996.0591w.x

Atkinson, T. J., \& Halfon, M. S. (2014). Regulation of gene expression in the genomic context. Computational and Structural Biotechnology Journal, 9, 1-9. https://doi.org/10.5936/csbj.201401001

Ber, R., \& Daniel, V. (1992). Structure and sequence of the growth hormone-encoding gene from Tilapia nilotica. Gene, 113, 245-250. https://doi.org/10.1016/0378-1119(92)90402-B

Bikandi, J., Millán, R. S., Rementeria, A., \& Garaizar, J. (2004). In silico analysis of complete bacterial genomes: PCR, AFLP-PCR and endonuclease restriction. Bioinformatics, 20, 798-799. https://doi. org/10.1093/bioinformatics/btg491

Blanck, D. V., Gasparino, E., Ribeiro, R. P., \& Marques, D. S. (2009). Polymorphism in the GH1-Pstl gene associated to corporal characteristics in Nile tilapia strains. Pesquisa Agropecuária Brasileira, 44, 599-604. https://doi.org/10.1590/S0100-204X2009000600008

Cavari, B., Funkenstein, B., Chen, T. T., Gonzalez-Villasenor, L. I., \& Schartl, M. (1993). Effect of growth hormone on the growth rate of the gilthead seabream (Sparus aurata), and use of different constructs for the production of transgenic fish. Aquaculture, 111, 189197. https://doi.org/10.1016/B978-0-444-81527-9.50022-1

Chen, T. T., Kight, K., Lin, C. M., Powers, D. A., Hayat, M., Chatakondi, N., Ramboux, A. C., Duncan, P. L., \& Dunham, R. A. (1993). Expression and inheritance of RSVLTR-rtGHI complementary DNA in transgenic common carp, Cyprinus carpio. Molecular Marine Biology and Biotechnology, 2, 88-95.

Chiou, C. S., Chen, H. T., \& Chang, W. C. (1990). The complete nucleotide sequence of the growth-hormone gene from the common carp (Cyprinus carpio). Biochimica Et Biophysica Acta, 1087, 91-94. https:// doi.org/10.1016/0167-4781(90)90126-M

Corrêa, M. A., Kahn, J. R., \& Freitas, C. E. C. (2014). Perverse incentives in fishery management: The case of the defeso in the Brazilian Amazon. Ecological Economics, 106, 186-194. https://doi.org/10.1016/j.ecole con.2014.07.023

Curi, R. A., Palmieri, D. A., Suguisawa, L., Oliveira, H. N., Silveira, A. C., \& Lopes, C. R. (2006). Growth and carcass traits associated with GH1/ Alu I and POU1F1/Hinf I gene polymorphisms in Zebu and crossbred 
beef cattle. Genetics and Molecular Biology, 29, 56-61. https://doi. org/10.1590/S1415-47572006000100012

De-Santis, C., \& Jerry, D. R. (2007). Candidate growth genes in finfishWhere should we be looking? Aquaculture, 272, 22-38. https://doi. org/10.1016/j.aquaculture.2007.08.036

Devlin, R. H., D'Andrade, M., Uh, M., \& Biagi, C. A. (2004). Population effects of growth hormone transgenic coho salmon depend on food availability and genotype by environment interactions. Proceedings of National Academy of Sciences of the United States of America, 101, 9303-9308. https://doi.org/10.1073/pnas.0400023101

Dias, M. A., Neto, R. V., Filho, S. B., Jaser, S. K., Lago, A., \& Hilsdorf, A. W. (2019). Growth hormone gene polymorphism associated with growout performance of Oreochromis niloticus strains. Aquaculture, 503, 105-110. https://doi.org/10.1016/j.aquaculture.2018.12.069

Du, S. J., Gong, Z., Fletcher, G. L., Shears, M. A., King, M. J., Idler, D. R., \& Hew, C. L. (1992). Growth enhancement in transgenic Atlantic salmon by the use of an 'all-fish' chimeric growth hormone gene construct. Biotechnology, 10, 176-181. https://doi.org/10.1038/nbt0292-176

Dunham, R. A., Ramboux, A., Duncan, P. L., Hayat, M. T., Chen, T. T., Lin, C. M., Kight, K. E., Gonzalez-Villasenor, I., \& Powers, D. A. (1992). Transfer, expression, and inheritance of salmonid growth hormone genes in channel catfish, Ictalurus punctatus, and effects on performance traits. Molecular Marine Biology and Biotechnology, 1, 380-389.

Excoffier, L., Laval, G., \& Schneider, S. (2005). Arlequin (version 3.0): An integrated software package for population genetics data analysis. Evolutionary Bioinformatics, 1, 47-50. https://doi.org/10.1177/11769 3430500100003

Fuji, K., Hasegawa, O., Honda, K., Kumasaka, K., Sakamoto, T., \& Okamoto, N. (2007). Marker-assisted breeding of a lymphocystis diseaseresistant Japanese flounder (Paralichthys olivaceus). Aquaculture, 272, 291-295. https://doi.org/10.1016/j.aquaculture.2007.07.210

Gopal, N. G., Singh, S. D., Kumari, V., \& Pandey, A. K. (2015). Molecular analysis of dinucleotide microsatellite in the growth hormone gene of Asian seabass (Lates calcarifer) from Mumbai, India. Journal of Environmental Biology, 36, 289-294. Retrieved from https://pubmed. ncbi.nlm.nih.gov/26536806/

Goudet, J. (1994). FSTAT (version 1.2): A computer program to calculate F-statistics. Journal of Heredity, 86, 485-486. https://doi. org/10.1093/oxfordjournals.jhered.a111627

Gross, M. L., Schneider, J. F., Moav, N., Moav, B., Alvarez, C., Myster, S. H., Liu, Z., Hallerman, E. M., Hackett, P. B., Guise, K. S., \& Faras, A. J. (1992). Molecular analysis and growth evaluation of northern pike (Esox lucius) microinjected with growth hormone genes. Aquaculture, 103, 253-273. https://doi.org/10.1016/0044-8486(92)90171-G

Gross, R., \& Nilsson, J. (1999). Restriction fragment length polymorphism at the growth hormone 1 gene in Atlantic salmon (Salmo salar L.) and its association with weight among the offspring of a hatchery stock. Aquaculture, 173, 73-80. https://doi.org/10.1016/S0044 -8486(98)00470-0

Hale, C. S., Herring, W. O., Shibuya, H., Lucy, M. C., Lubahn, D. B., Keisler, D. H., \& Johnson, G. S. (2000). Decreased growth in Angus steers with a short TG-microsatellite allele in the P1 promoter of the growth hormone receptor gene. Journal of Animal Science, 78, 2099-2104. https://doi.org/10.2527/2000.7882099x

Hall, T. A. (1999). BioEdit: A user-friendly biological sequence alignment editor and analysis program for Windows 95/98/NT. Nucleic Acids Symposium Series, 41, 95-98.

Hallerman, E. M., McLean, E., \& Fleming, I. A. (2007). Effects of growth hormone transgenes on the behavior and welfare of aquacultured fishes: A review identifying research needs. Journal of Applied Animal Behaviour Science, 104, 265-294. https://doi.org/10.1016/j.appla nim.2006.09.008

Higgins, D. G. (1994). CLUSTAL V: Multiple alignment of DNA and protein sequences. Methods in Molecular Biology, 25, 307-318. https:// doi.org/10.1385/0-89603-276-0:307
Horan, M., Millar, D. S., Hedderich, J., Lewis, G., Newsway, V., Mo, N., Fryklund, L., Procter, A. M., Krawczak, M., \& Cooper, D. N. (2003). Human growth hormone 1 (GH1) gene expression: Complex haplotype-dependent influence of polymorphic variation in the proximal promoter and locus control region. Human Mutation, 21, 408-423. https://doi.org/10.1002/humu.10167

IBGE. (2019). Instituto Brasileiro de Geografia e Estatística, Pesquisa da Pecuária Municipal-PPM, Tabela 5 - Produção da aquicultura, por tipo de produto, segundo o Brasil, as Grandes Regiões e as Unidades da Federação. (2019, April 28). Retrieved from https://www.ibge.gov.br/ estatisticas/economicas/agricultura-e-pecuaria/9107-producao-dapecuaria-municipal.html?=\&t=resultados

Isaac, V. J., \& Ruffino, M. L. (1996). Population dynamics of tambaqui, Colossoma macropomum Cuvier, in the Lower Amazon, Brazil. Fisheries Management and Ecology, 3, 315-333. https://doi.org/10.1046/ j.1365-2400.1996.d01-154.x

Jaser, S. K., Dias, M. A., Lago, A. D., Reis Neto, R. V., \& Hilsdorf, A. W. S. (2017). Single nucleotide polymorphisms in the growth hormone gene of Oreochromis niloticus and their association with growth performance. Aquaculture Research, 48, 5835-5845. https://doi. org/10.1111/are.13406

Kang, J. H., Lee, S. J., Park, S. R., \& Ryu, H. Y. (2002). DNA polymorphism in the growth hormone gene and its association with weight in olive flounder Paralichthys olivaceus. Fisheries Science, 68, 494-498. https://doi.org/10.1046/j.1444-2906.2002.00453.x

Kashi, Y., \& King, D. G. (2006). Simple sequence repeats as advantageous mutators in evolution. Trends in Genetics, 22, 253-259. https://doi. org/10.1016/j.tig.2006.03.005

Kashi, Y., King, D., \& Soller, M. (1997). Simple sequence repeats as a source of quantitative genetic variation. Trends in Genetics, 13, 7478. https://doi.org/10.1016/S0168-9525(97)01008-1

Kocour, M., \& Kohlmann, K. (2011). Growth hormone gene polymorphisms in tench, Tinca tinca L. Aquaculture, 310, 298-304. https:// doi.org/10.1016/j.aquaculture.2010.10.006

Kuhnlein, U., Ni, L., Weigend, S., Gavora, J. S., Fairfull, W., \& Zadworny, D. (1997). DNA polymorphisms in the chicken growth hormone gene: Response to selection for disease resistance and association with egg production. Animal Genetics, 28, 116-123. https://doi. org/10.1111/j.1365-2052.1997.00076.x

Li, M. J., Liu, W. S., Luo, W., Zhang, X. Q., Zhu, W. L., Wang, J., Liao, L. Y., $\&$ Li, G. H. (2017). Polymorphisms and their association with growth traits in the growth hormone gene of yellow catfish, Pelteobagrus fulvidraco. Aquaculture, 469, 117-123. https://doi.org/10.1016/j.aquac ulture.2016.11.028

Li, Y. C., Korol, A. B., Fahima, T., \& Nevo, E. (2004). Microsatellites within genes: Structure, function, and evolution. Molecular Biology and Evolution, 21, 991-1007. https://doi.org/10.1093/molbev/ msh073

Liu, X., Liang, H., Liang, Y., Li, Z., Qin, X., Zhang, T., Zhang, J., Zou, G., \& Hu, G. (2017). Significant associations of polymorphisms in the growth hormone gene with growth traits in common carp (Cyprinus carpio). Meta Gene, 14, 38-41. https://doi.org/10.1016/j.mgene.2017.07.008

Liu, Y. G., \& Whittier, R. F. (1995). Thermal asymmetric interlaced PCR: Automatable amplification and sequencing of insert end fragments from P1 and YAC clones for chromosome walking. Genomics, 25, 674-681. https://doi.org/10.1016/0888-7543(95)80010-J

Ma, Q., Liu, S. F., Zhuang, Z. M., Lin, L., Sun, Z. Z., Liu, C. L., Ma, H., Su, Y. Q., \& Tang, Q. S. (2012). Genomic structure, polymorphism and expression analysis of the growth hormone (GH) gene in female and male half-smooth tongue sole (Cynoglossus semilaevis). Gene, 493, 92104. https://doi.org/10.1016/j.gene.2011.11.015

Ma, Q., Liu, S. F., Zhuang, Z. M., Lin, L., Sun, Z. Z., Liu, C. L., Su, Y. Q., \& Tang, Q. S. (2011). Genomic structure, polymorphism and expression analysis of growth hormone-releasing hormone and pituitary adenylate cyclase activating polypeptide genes in the half-smooth 
tongue sole (Cynoglossus semilaevis). Genetics and Molecular Research, 10, 3828-3846. https://doi.org/10.1016/j.gene.2011.11.015

Marshall, T. C., Slate, J., Kruuk, L. E. B., \& Pemberton, J. M. (1998). Statistical confidence for likelihood-based paternity inference in natural populations. Molecular Ecology, 7, 639-655. https://doi. org/10.1046/j.1365-294x.1998.00374.x

Martinez, R., Estrada, M. P., Berlanga, J., Guillen, I., Hernandez, O., Cabrera, E., Pimentel, R., Morales, R., Herrera, F., Morales, A., Pina, J. C., Abad, Z., Sanchez, V., Melamed, P., Lleonart, R., \& De la Fuente, J. (1996). Growth enhancement in transgenic tilapia by ectopic expression of tilapia growth hormone. Molecular Marine Biology and Biotechnology, 5, 62-70.

Messeguer, X., Escudero, R., Farre, D., Nunez, O., Martinez, J., \& Alba, M. M. (2002). PROMO: Detection of known transcription regulatory elements using species-tailored searches. Bioinformatics, 18, 333-334. https://doi.org/10.1093/bioinformatics/18.2.333

Miller, W. L., \& Eberhardt, N. L. (1983). Structure and evolution of the growth hormone gene family. Endocrine Reviews, 4, 97-130. https:// doi.org/10.1210/edrv-4-2-97

Moen, T. (2010). Breeding for resistance to viral diseases in salmonids. In S. C. Bishop, R. F. E. Axford, F. W. Nicholas, \& J. B. Owen (Ed.), Breeding for disease resistance in farm animals (3rd. ed., pp. 166-179). CAB International.

Moriyama, S., Oda, M., Takahashi, A., Sower, S. A., \& Kawauchi, H. (2006). Genomic structure of the sea lamprey growth hormone-encoding gene. General and Comparative Endocrinology, 148, 33-40. https:// doi.org/10.1016/j.ygcen.2005.09.023

Parinov, S., Kondrichin, I., Korzh, V., \& Emelyanov, A. (2004). Tol2 transposon-mediated enhancer trap to identify developmentally regulated zebrafish genes in vivo. Developmental Dynamics, 231, 449459. https://doi.org/10.1002/dvdy.20157

Pereira, A. P., Alencar, M. M., Oliveira, H. N., \& Regitano, L. C. (2005). Association of GH and IGF-1 polymorphisms with growth traits in a synthetic beef cattle breed. Genetics and Molecular Biology, 28, 230236. https://doi.org/10.1590/S1415-47572005000200009

Pinheiro, J. S., Wolff, J. L., Araújo, R. D., \& Hilsdorf, A. W. (2008). Molecular cloning and sequence analysis of growth hormone cDNA of Neotropical freshwater fish pacu (Piaractus mesopotamicus). Genetics and Molecular Biology, 31, 381-384. https://doi.org/10.1590/S1415 $-47572008000200037$

Poen, S., \& Pornbanlualap, S. (2013). Growth hormone from striped catfish (Pangasianodon hypophthalmus): Genomic organization, recombinant expression and biological activity. Gene, 518, 316-324. https:// doi.org/10.1016/j.gene.2013.01.014

Pompanon, F., Bonin, A., Bellemain, E., \& Taberlet, P. (2005). Genotyping errors: Causes, consequences and solutions. Nature Reviews Genetics, 6, 847-859. https://doi.org/10.1038/nrg1707

Poompuang, S., \& Hallerman, E. M. (1997). Toward detection of quantitative trait loci and marker-assisted selection in fish. Reviews in Fisheries Science, 5, 253-277. https://doi.org/10.1080/10641269709388600

Quéré, N., Guinand, B., Kuhl, H., Reinhardt, R., Bonhomme, F., \& Desmarais, E. (2010). Genomic sequences and genetic differentiation at associated tandem repeat markers in growth hormone, somatolactin and insulin-like growth factor-1 genes of the sea bass, Dicentrarchus labrax. Aquatic Living Resources, 23, 285-296. https:// doi.org/10.1051/alr/2010021

Roy, A. L., \& Singer, D. S. (2015). Core promoters in transcription: Old problem, new insights. Trends in Biochemical Sciences, 40, 165-171. https://doi.org/10.1016/j.tibs.2015.01.007

Russell, D. W., Smith, M., Cox, D., Williamson, V. M., \& Young, E. T. (1983). DNA-sequences of 2 yeast promoter-up mutants. Nature, 304, 652654. https://doi.org/10.1038/304652a0

Sakamoto, T., Shepherd, B. S., Madsen, S. S., Nishioka, R. S., Siharath, K., Richman, N. H., Bern, H. A., \& Grau, E. G. (1997). Osmoregulatory actions of growth hormone and prolactin in an advanced teleost.
General and Comparative Endocrinology, 106, 95-101. https://doi. org/10.1006/gcen.1996.6854

Sambrook, J., \& Russell, D. W. (2006). The condensed protocols from molecular cloning: A laboratory manual. Cold Spring Harbor, N.Y.: Cold Spring Harbor Laboratory Press.

Sánchez-Ramos, I., Barrios, M., Cross, I., \& Rebordinos, L. (2006). Identificación de RFLP en genes relacionados con el crecimiento en dorada Sparus aurata L., 1758. Boletín - Instituto Español De Oceanografía, 21, 253-259. Retrieved from http://hdl.handle. net/10508/1419

Schuelke, M. (2000). An economic method for the fluorescent labeling of PCR fragments. Nature Biotechnology, 18, 233-234. https://doi. org $/ 10.1038 / 72708$

Sekkali, B., Brim, H., Muller, M., Argenton, F., Bortolussi, M., Colombo, L., Belayew, L., \& Martial, J. A. (1999). Structure and functional analysis of a tilapia (Oreochromis mossambicus) growth hormone gene: Activation and repression by pituitary transcription factor Pit-1. DNA and Cell Biology, 18, 489-502. https://doi.org/10.1089/1044549993 15213

Sellier, P. (2000). Genetically caused retarded growth in animals. Domestic Animal Endocrinology, 19, 105-119. https://doi.org/10.1016/S0739 $-7240(00) 00071-0$

Session, A., Burke, E., Presting, G., Aux, G., McElver, J., Patton, D., Dietrich, B., Ho, P., Bacwaden, J., Ko, C., Clarke, J. D., Cotton, D., Bullis, D., Snell, J., Miguel, T., Hutchison, D., Kimmerly, B., Mitzel, T., Katagiri, F., ... Goff, S. A. (2002). A high-throughput Arabidopsis reverse genetics system. The Plant Cell, 14, 2985-2994. https://doi. org/10.1105/tpc.004630

Silverstein, J. T., Wolters, W. R., Shimizu, M., \& Dickhoff, W. W. (2000). Bovine growth hormone treatment of channel catfish: Strain and temperature effects on growth, plasma IGF-I levels, feed intake and efficiency and body composition. Aquaculture, 190, 77-88. https:// doi.org/10.1016/S0044-8486(00)00387-2

Sonesson, A. K. (2007). Possibilities for marker-assisted selection in aquaculture breeding schemes. In E. P. Guimarães J. Ruane D. Beate B. S. Scherf A. Sonnino \& J. D. Dargie (Eds.), Current status and future application in crops, livestock, forestry and fish (pp. 309-328). Rome: FAO.

Souza, C. J. H., Almeida, F. F. L., Franco, M. M., \& Melo, E. O. (2016). (2019, May 30). Colossoma macropomum growth hormone mRNA, partial cds. DNA sequence. Retrieved from https://www.ncbi.nlm. nih.gov/nuccore/KU312263

Streelman, J. T., \& Kocher, T. D. (2002). Microsatellite variation associated with prolactin expression and growth of salt-challenged tilapia. Physiological Genomics, 9, 1-4. https://doi.org/10.1152/physiolgen omics.00105.2001

Tamura, K., Peterson, D., Peterson, N., Stecher, G., Nei, M., \& Kumar, S. (2011). MEGA5: Molecular Evolutionary Genetics Analysis using maximum likelihood, evolutionary distance, and maximum parsimony methods. Molecular Biology and Evolution, 28, 2731-2739. https://doi. org $/ 10.1093 / \mathrm{molbev} / \mathrm{msr} 121$

Tang, Y., Lin, C. M., Chen, T. T., Kawauchi, H., Dunham, R. A., \& Powers, D. A. (1993). Structure of the channel catfish (Ictalurus punctatus) growth hormone gene and its evolutionary implications. Molecular Marine Biology and Biotechnology, 2, 198-206. Retrieved from https:// pubmed.ncbi.nlm.nih.gov/8293072/

Untergasser, A., Cutcutache, I., Koressaar, T., Ye, J., Faircloth, B. C., Remm, M., \& Rozen, S. G. (2012). Primer3 - New capabilities and interfaces. Nucleic Acids Research, 40, 1-12. https://doi.org/10.1093/ nar/gks596

Von Schalburg, K. R., Yazawa, R., De Boer, J., Lubieniecki, K. P., Goh, B., Straub, C. A., Beetz-Sargent, M. R., Robb, A., Davidson, W. S., Devlin, R. H., \& Koop, B. F. (2008). Isolation, characterization and comparison of Atlantic and Chinook salmon growth hormone 1 and 2. BMC Genomics, 9, 1-12. https://doi.org/10.1186/1471-2164-9-522 
Woelfle, J., Chia, D. J., \& Rotwein, P. (2003). Mechanisms of growth hormone $(\mathrm{GH})$ action: Identification of conserved Stat5 binding sites that mediate $\mathrm{GH}$-induced insulin-like growth factor-I gene activation. The Journal of Biological Chemistry, 278, 51261-51266. https:// doi.org/10.1074/jbc.M309486200

Yamada, S., Hata, J. I., \& Yamashita, S. (1993). Molecular cloning of fish Pit-1 cDNA and its functional binding to promoter of gene expressed in the pituitary. Journal of Biological Chemistry, 268, 24361-24366. https://doi.org/10.1016/S0021-9258(20)80534-1

Yowe, D. L., \& Epping, R. J. (1995). Cloning of the barramundi growth hormone-encoding gene: A comparative analysis of higher and lower vertebrate $\mathrm{GH}$ genes. Gene, 162, 255-259. https://doi. org/10.1016/0378-1119(95)92858-5

Yue, G., Li, Y., \& Orban, L. (2001). Characterization of microsatellites in the IGF-2 and GH genes of Asian seabass (Lates calcarifer). Marine Biotechnology, 3, 1-3. https://doi.org/10.1007/s101260000043

Zhang, C., Liu, Y., Huang, K., Zeng, W., Xu, D., Wen, Q., \& Yang, L. (2011). The association of two single nucleotide polymorphisms (SNPs) in growth hormone $(\mathrm{GH})$ gene with litter size and superovulation response in goat breeds. Genetics and Molecular Biology, 34, 49-55. https://doi.org/10.1590/S1415-47572010005000110
Zou, J. J., Trudeau, V. L., Cui, Z., Brechin, J., Mackenzie, K., Zhu, Z., Houlihan, D. F., \& Peter, R. E. (1997). Estradiol stimulates growth hormone production in female goldfish. General and Comparative Endocrinology, 106, 102-112. https://doi.org/10.1006/gcen.1996.6857

\section{SUPPORTING INFORMATION}

Additional supporting information may be found online in the Supporting Information section.

How to cite this article: Jaser SKK, Perazza CA, Fávaro LCL, et al. Identification and analysis of a novel microsatellite marker within the growth hormone gene promoter of Colossoma macropomum (Characiformes: Characidae) detected by TAIL-PCR. J Appl Ichthyol. 2021;00:1-10. https:// doi.org/10.1111/jai.14170 